\title{
GnRH and oxytocin have nonidentical effects on the cellular LH response by gonadotrophs at pro-oestrus
}

\author{
J J Evans ${ }^{1}$, A H Youssef ${ }^{1}$, M M Abbas ${ }^{1}$ and J Schwartz ${ }^{2}$ \\ ${ }^{1}$ University Department of Obstetrics and Gynaecology, Christchurch School of Medicine, Private Bag 4711, Christchurch, New Zealand \\ ${ }^{2}$ Department of Obstetrics and Gynecology, Wake Forest University, Winston-Salem, North Carolina 27157, USA \\ (Requests for offprints should be addressed to J J Evans, Department of Obstetrics and Gynaecology, Christchurch Women's Hospital, Private Bag 4711, \\ Christchurch, New Zealand; Email: john.evans@chmeds.ac.nz)
}

\begin{abstract}
For full fertility in the female ovulation is necessary, which is dependent on the production of a surge of LH. An understanding of the processes which result in the high levels of $\mathrm{LH}$ requires delineation of the activities of individual component cells. In this study the responses of gonadotrophs to two signalling hypothalamic peptides, $\mathrm{GnRH}$ and oxytocin, were investigated. A cell immunoblot method was used to identify and distinguish between cells which secrete LH and those which contain LH but do not secrete the glycohormone. Rats were killed on the morning of pro-oestrus, the pituitary collected and the cells dispersed onto a protein-binding membrane for study. Cells were then incubated with GnRH and oxytocin, after which the membranes including the attached cells were stained by immunocytochemistry for LH. $\mathrm{GnRH}$ increased the total number of immunopositive cells which were present in a concentration-dependent manner. The most prominent change after $2 \mathrm{~h}$ incubation was in the number of secreting cells, whereas after $4 \mathrm{~h}$ there was also a marked increase in numbers of nonsecret-
\end{abstract}

ing cells. Oxytocin also increased the total number of immunopositive cells in a concentration-responsive manner, however the profile of action of oxytocin was different from that observed for GnRH. Oxytocin had a relatively greater effect on numbers of immunopositive nonsecreting cells. Thus, the results reveal the potential for gonadotrophs to be flexibly and appropriately modulated by selected hypothalamic peptides. When cells were preincubated with oxytocin prior to GnRH there was not an additive increase in the numbers of immunopositive cells, suggesting that the two agonists act, in a nonidentical manner, on similar cells. The increase in the total number of immunopositive cells implies that there was a production of $\mathrm{LH}$ or post-translational processing, induced by exposure to GnRH or oxytocin. The results confirmed the heterogeneity of gonadotrophs and the existence of functionally distinguishable subpopulations, and revealed a difference between the effects of GnRH and oxytocin on expression and secretion of $\mathrm{LH}$.

Journal of Endocrinology (1999) 163, 345-351

\section{Introduction}

The production of the regular ovulatory cycle is a result of the interaction of many co-ordinated factors. It is known, for example, that there are regular fluctuations in ovarian steroids and ovarian proteins. An important process is the preovulatory luteinising hormone (LH) surge which is preceded by a surge of gonadotrophin-releasing hormone (GnRH) from the hypothalamus (Sherwood et al. 1980). However, the detailed cellular response of the functional pituitary to the exposure to $\mathrm{GnRH}$, either endogenous or exogenous, is only scantily understood. For example, pituitary responses to $\mathrm{GnRH}$ are altered as a function of the oestrus cycle, and the ways in which the characteristics of gonadotrophs change is still to be established. One of the main problems in defining the response of the pituitary is the now well recognised heterogeneity of the gland. Not only is it made of several classical secretory cell types, but also within the population of gonadotrophs there are a number of subpopulations which can be defined on the basis of function.

Differences between gonadotrophs were noticed many years ago, including differences in size (Denef et al. 1978, Childs et al. 1992a), morphology (Childs et al. 1980), whether LH and/or FSH were present in a cell (Dada et al. 1983), physical density (Torronteras et al. 1993b), and ultrastructural characteristics (Torronteras et al. 1993a, Malagon et al. 1998). There was a change in density of LH staining within cells during the cycle (Childs et al. 1987), presumably reflecting secretion patterns culminating in the LH surge. It was suggested that gonadotrophs change among being monohormonal or bihormonal, and reserve, storage or secretory cells as parts of a cycle (reviewed in Childs 1995).

In vitro, gonadotrophs respond to $\mathrm{GnRH}$ by secreting $\mathrm{LH}$ and by increasing intracellular $\mathrm{LH}$ stores. A fuller 
understanding of the manner in which pro-oestrus gonadotrophs behave in the pituitary in vivo prior to the preovulatory surge has been limited by insufficient knowledge of the manner in which individual cells, from single rats, respond under particular circumstances. The regulated progression of the ovulatory cycle may be dependent on the ratios of cells which secrete $\mathrm{LH}$ in response to GnRH and those which do not.

In addition, the pituitary response is regulated by several factors besides GnRH. A number of other hypothalamic peptides, in particular oxytocin (Evans 1996), have also been observed to alter gonadotroph behaviour. Pharmacological blockade of oxytocin inhibits the preovulatory LH surge in female rats at pro-oestrus (Johnston \& Negro-Vilar 1988, Robinson \& Evans 1990). In vitro oxytocin increases secretion of LH from dispersed pituitary cells and stimulates an increase in intracellular $\mathrm{Ca}^{2+}$ in both dispersed normal pituitary cells and the $\alpha \mathrm{T} 31$ cell line (Billiard 1996, Evans et al. 1997). However, oxytocin and GnRH do not have identical activities. Oxytocin is less potent than $\mathrm{GnRH}$ in stimulating secretion of LH. There are also differences in the manner in which GnRH and oxytocin induce desensitisation. Oxytocin reduces responsiveness to the homologous peptide more rapidly than GnRH (Evans et al. 1997). Oxytocin is also known to induce synthesis of LH in pituitary cells (Robinson et al. 1992). To our knowledge there are no studies on the response of individual pro-oestrus cells to oxytocin.

This study investigated the manner in which individual gonadotrophs respond to GnRH or oxytocin by comparing the numbers of cells which secreted LH and those which contained $\mathrm{LH}$ but did not respond by releasing stores. A cell immunoblot method, based on immunohistochemical techniques, was employed. The method is well established (Kendall \& Hymer 1987, Arita 1993) and has been used for several applications at the pituitary, including the detection of prolactin (Kendall \& Hymer 1987, Arita et al. 1991), substance P (Arita et al. 1993), ACTH (Perez et al. 1997) and FSH (Noguchi et al. 1996). In this study we have examined the regulation of $\mathrm{LH}$. The method labels both LH in cells, and LH secreted from cells and adhering to a protein binding membrane. By visualising and counting nonsecreting and secreting cells we have been able to observe specific and nonidentical effects of two agonists (GnRH and oxytocin) on individual gonadotrophs.

\section{Materials and Methods}

Female rats were kept in controlled conditions with a ratio of $14 \mathrm{~h}$ light: $10 \mathrm{~h}$ darkness (lights on $0500 \mathrm{~h}$, off $1900 \mathrm{~h}$ ). The studies were carried out in accordance with the principles and procedures of the animal ethics committee of the Christchurch School of Medicine. Oestrus cycles were monitored by cytology of vaginal smears taken daily.
Rats which had had at least three consecutive 4-day oestrus cycles were used and were killed at $0900 \mathrm{~h}$ on the day of pro-oestrus. Pituitaries were collected and diced in medium consisting of $500 \mathrm{ml}$ DMEM including $0.11 \mathrm{~g}$ sodium pyruvate, $4000 \mathrm{mg} / \mathrm{l}$ glucose (Gibco BRL Products, Gaithersburg, MD, USA) supplemented with $1.8 \mathrm{~g}$ Hepes, $1.5 \mathrm{~g}$ BSA, $800 \mathrm{U}$ penicillin, $800 \mu \mathrm{g}$ streptomycin and $1 \mathrm{mg}$ amphotericin. The tissue was digested in the above medium $(1 \mathrm{ml})$ with $3 \mathrm{mg}$ trypsin and $1 \mathrm{mg}$ DNase, shaking at $37^{\circ} \mathrm{C}$ for $13 \mathrm{~min}$. The partially dispersed cells were triturated in the medium ( $5 \mathrm{ml} /$ pituitary) with $10 \mathrm{mg}$ trypsin inhibitor, $1 \mathrm{mg}$ DNase. The cells were filtered through gauze, washed and counted and viability assessed with trypan blue. Cells were suspended in Medium 199 (Gibco BRL Products) with Hanks' salts and L-glutamine, containing in 1 litre $1.40 \mathrm{~g}$ sodium bicarbonate, 5.95 g Hepes (Sigma-Aldrich, Castle Hill, Australia), $1 \mathrm{~g}$ BSA, $10 \mathrm{ml}$ penicillin/streptomycin (Sigma-Aldrich) at $\mathrm{pH} 7 \cdot 4$.

For the cell immunoblotting procedure $1.5 \times 10^{4}$ cells in a $80 \mu \mathrm{l}$ droplet were added to a square of Immobilon P membrane (Millipore Corporation, Bedford, MA, USA). The cells were allowed to settle for $30 \mathrm{~min}$, after which time test agent (GnRH or oxytocin) was added in $8 \mu$ to the droplet to give final concentrations of $0 \cdot 1-100 \mathrm{nM}$. When incubation was performed with oxytocin in combination with $\mathrm{GnRH}$, the $\mathrm{GnRH}$ was added $30 \mathrm{~min}$ after oxytocin to the same droplet. The membranes were incubated in a humidified chamber at $37{ }^{\circ} \mathrm{C}$ for 2 or $4 \mathrm{~h}$. Following the designated time the spent medium was discarded, the cells were washed and $100 \mu \mathrm{l} 2.5 \%$ glutaraldehyde added as fixative. The fixed cells were washed (Tris buffer, $\mathrm{pH} \mathrm{8.2)} \mathrm{and} \mathrm{incubated} \mathrm{overnight} \mathrm{in} \mathrm{Tris}$ buffer containing 3\% BSA.

For staining, primary antibody (anti-LH raised in guinea-pigs; National Hormone and Pituitary Program) was added, followed by secondary antibody (anti-guineapig IgG coupled to biotin; Sigma-Aldrich). The site of LH immunoreactivity was visualised using avidin coupled to alkaline phosphatase, and substrate which was converted to a red product (Vector Laboratories, Burlingham, CA, USA). The membranes were covered with a cover slip over glycerol. The cells were viewed and counted with an oil immersion lens. Controls in which the primary antibody or the secondary antibody were omitted or which used primary antibody which was preadsorbed with $\mathrm{LH}$ indicated the specificity of the staining protocol.

Cells containing LH stained red (Fig. 1a). Secretion was observed as a region of red staining of membrane-bound protein outside a cell (Fig. 1b). Cells were counted manually by investigators blinded to the treatment of the cells. An average of 300 cells were counted per membrane, using an eyepiece grid and serpentine counting. Cells which exhibited secretion were counted into a category separate from those which were immunopositive but for which no staining outside the cell was seen. The sum of 

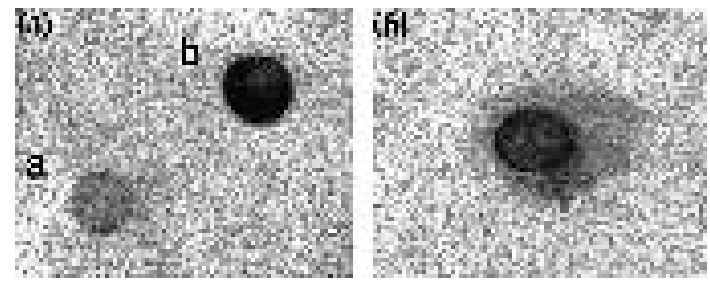

Figure 1 a: A cell which did not stain for LH (a) and an LH-immunopositive cell (b). $b$ : An example of a cell which secreted LH. The stained secretion is seen as a dark area around this cell.

the two categories produced the total of immunopositive cells. The stained cells were calculated as a percent of the total number of cells on the membrane. Thus, percentage of immunopositive cells which were nonsecreting, and which were secreting, and total immunopositive cells were determined. A set of experiments utilised one pituitary, each condition being examined on usually four different blots and the means determined. Each experiment was performed at least three times on different rats, and the means \pm S.E.M of the treatments were calculated. Comparison between groups was performed using one way ANOVA, and the appropriate Tukey test or KruskalWallis analysis of variance on ranks. $P<0 \cdot 05$ was taken to indicate statistically significant differences.

\section{Results}

\section{GnRH}

After $2 \mathrm{~h}$ of exposure to GnRH, the total number of LH-immunopositive cells increased significantly. The response occurred in a concentration-dependent manner such that higher concentrations of GnRH induced the appearance of more immunopositive cells (Fig. 2). By separately noting the effect on numbers of secreting cells and nonsecreting cells more information could be obtained regarding the response of individual cells to GnRH. Although there was a small change in the numbers of nonsecreting cells, there was a larger increase in secreting cells induced by the GnRH. The effect was significant at concentrations of $1 \mathrm{nM}$ and above, reinforcing the notion that the response is concentration-dependent.

The effects of a $4 \mathrm{~h}$ incubation were different to those of the $2 \mathrm{~h}$ incubation. At $4 \mathrm{~h} \mathrm{GnRH}$ also markedly increased the numbers of nonsecreting cells. The differences in the percent of nonsecreting cells between the two times were statistically significant at $1 \mathrm{nM}(P=0.02)$ and $10 \mathrm{nM}(P<0 \cdot 05) \mathrm{GnRH}$. This suggests a time-dependent effect of $\mathrm{GnRH}$ to increase the levels of $\mathrm{LH}$ within certain responsive cells. On the other hand, there were no significant differences between numbers of secretory cells after $2 \mathrm{~h}$ compared with $4 \mathrm{~h}$ at each concentration.

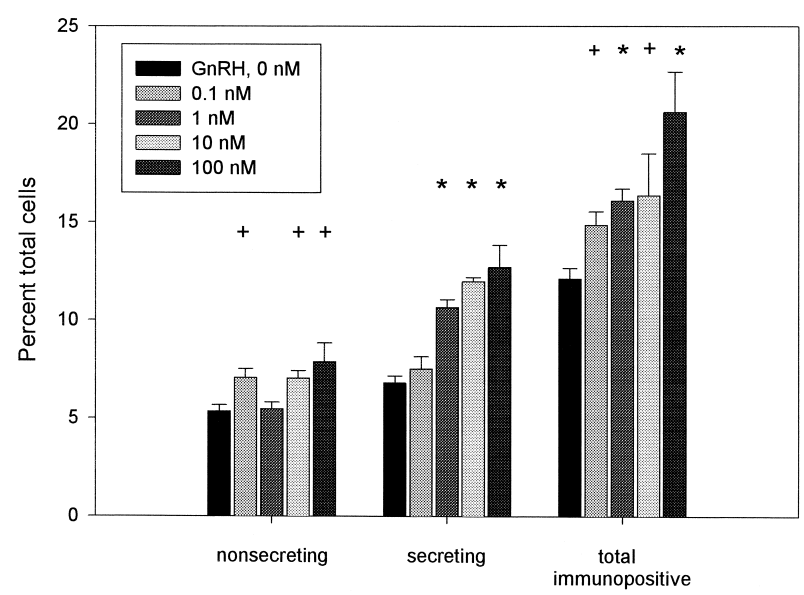

Figure 2 Cells were incubated without GnRH and with selected concentrations of GnRH for $2 \mathrm{~h}$. The percent of total pituitary cells which contained $\mathrm{LH}$ but did not secrete $\mathrm{LH}$, the percent of total cells which secreted $\mathrm{LH}$ and the total number of immunopositive cells were calculated. The means \pm S.E.M. are depicted. Compared with incubations without GnRH: ${ }^{+} P<0 \cdot 05 ;{ }^{*} P<0 \cdot 002$.

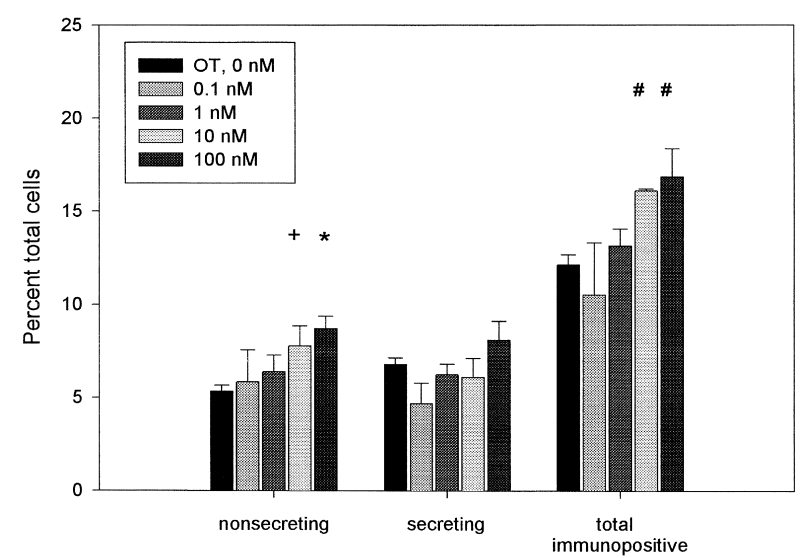

Figure 3 Cells were incubated without oxytocin (OT) and with selected concentrations of oxytocin for $2 \mathrm{~h}$. The percent of total pituitary cells which contained LH but did not secrete $\mathrm{LH}$, the percent of total cells which secreted $\mathrm{LH}$ and the total number of immunopositive cells were calculated. Compared with incubations without oxytocin: ${ }^{+} P<0 \cdot 05 ;{ }^{\#} P<0 \cdot 01 ;{ }^{\star} P<0 \cdot 002$.

\section{Oxytocin}

In a similar manner we investigated the effects of oxytocin. During a $2 \mathrm{~h}$ incubation oxytocin increased the numbers of immunopositive cells (Fig. 3). In contrast to the effect of $\mathrm{GnRH}$ at $2 \mathrm{~h}$, oxytocin had a relatively lesser effect on secreting cells, and a prominent effect on increasing the number of immunopositive nonsecreting cells. At $4 \mathrm{~h}$ exposure oxytocin also increased the total numbers of immunopositive cells (data not shown).

\section{GnRH plus oxytocin}

The effect of adding GnRH to oxytocin was investigated with $2 \mathrm{~h}$ incubations (Fig. 4). Preincubation with oxytocin 


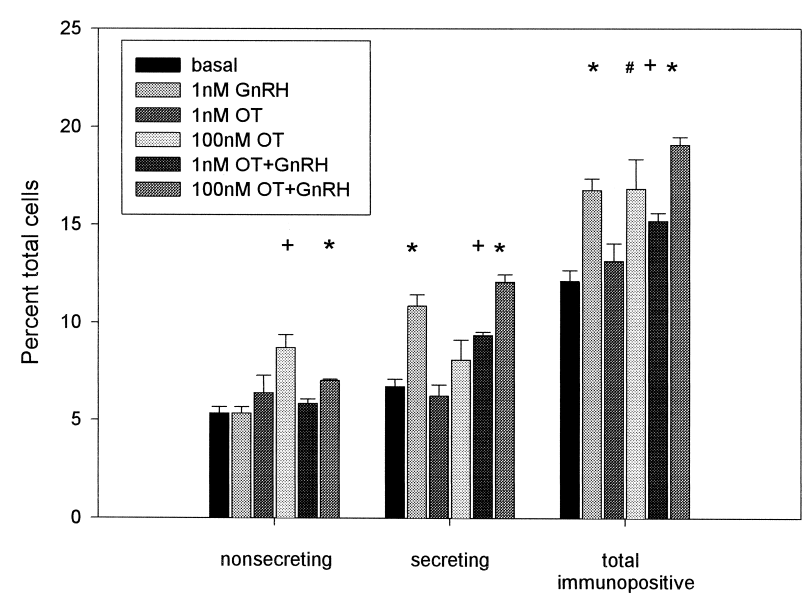

Figure 4 Cells were incubated with $\mathrm{GnRH}(1 \mathrm{nM})$, with oxytocin (OT, 1 or $100 \mathrm{nM}$ ) or a combination of oxytocin and $\mathrm{GnRH}$, as described in Methods, for $2 \mathrm{~h}$. The percent of total pituitary cells which contained $\mathrm{LH}$ but did not secrete $\mathrm{LH}$, the percent which secreted $\mathrm{LH}$ and the percent of total cells which were immunopositive cells were calculated. Compared with incubations without peptide: ${ }^{+} P<0 \cdot 05 ;{ }^{\#} P<0 \cdot 01 ;{ }^{*} P<0 \cdot 002$.

has been previously shown to affect the secretory response to GnRH (Evans et al. 1995). In this study when cells were preincubated with oxytocin prior to stimulation with GnRH there was no significant increase in the number of total immunopositive cells over the numbers seen when cells were incubated with GnRH alone. However, GnRH added to oxytocin produced a shift in the distribution of immunopositive cells, such that there was an increase in the number of secreting cells (oxytocin plus GnRH vs oxytocin, $P<0 \cdot 05)$, and a decrease in the number of nonsecreting cells.

\section{Discussion}

The cell immunoblot method provides a sensitive and specific analysis of the response of individual cells to stimulation by gonadotrophin-regulating peptides. The total numbers of immunopositive cells in pro-oestrus pituitaries incubated in basal conditions was similar to that observed in previous studies using conventional methods of immunocytochemistry (Childs et al. 1987, 1992b, 1997). The cells prepared for the protocol of this study were functional as indicated by the responses to agonist peptides. The cell immunoblot method employs acutely prepared cells which are not subject to culture artefacts, such as those observed in cells cultured for more than $48 \mathrm{~h}$ which lose differential properties that were acquired in vivo (Tomic et al. 1994). Thus, this method has the ability to study behaviour of dispersed cells which reflect physiological characteristics, and these results and their relationship to others must be interpreted with the particular properties of the methods in mind.
The cell immunoblot has the advantage over most other methods in being able to assign secretion to individual cells, rather than population averages. The reverse haemolytic plaque assay (RHPA) is another method to detect secretion by individual cells. However, the RHPA may have a different detection profile than the present cell immunoblot technique. The RHPA method may be less sensitive than the current method because the numbers of immunopositive cells typically reported (Smith et al. 1984, Wei et al. 1995) are less than in the present investigation and in other studies using traditional immunocytochemical methods (Childs et al. 1987, 1992b, 1997). In addition, whereas RHPA uses aliquots on separate plates to consider LH within a cell and secreted LH (Lewis et al. 1989, Leong \& Thorner 1991, Cassina et al. 1995), the cell immunoblot method can be used to determine whether an individual immunopositive cell also secretes LH. For the first time we have studied LH from this perspective.

Numerous previous studies on the average response of whole populations have documented that when GnRH is added to dispersed pituitary cells there is an increased release of LH. The present study revealed that after $2 \mathrm{~h}$ incubation there was an increased number of secreting cells, suggesting therefore that the increase in secretion is due, at least in part, to a recruitment of more cells to the subpopulation of secreting cells than were present in the control incubation. The results are consistent with some previous observations. An increase in secreting cells in response to $\mathrm{GnRH}$ has been observed also using RHPA on pituitaries from pro-oestrus rats (Lewis et al. 1989). GnRH was also observed to increase numbers of secreting cells in cells fractionated by elutriation from rats at mixed cycle stages (Lloyd \& Childs 1988). The present study exploited the properties of the immunoblot method to obtain information on the cellular responses of cells from single rats at a defined stage of the ovulatory cycle.

The present results reveal also that there is a heterogeneity among the group of potential LH-secreting cells of pro-oestrus, because some have an apparently higher threshold of activation than others, as revealed by the concentration-sensitive nature of the responses. Our observations are consistent with some previous observations (Lewis et al. 1989, Leong \& Thorner 1991) but contrast with some others, using RHPA, in which virtually all cells were secreting (Smith \& Neill 1987). In fact, our studies provide further support for the hypothesis that response thresholds are a major means of regulating responses (Leong \& Thorner 1991).

Given the observations of biological heterogeneity (Denef et al. 1978, Childs et al. 1980, 1992a, Dada et al. 1983) it can be inferred that some cells develop different intracellular responses to other cells. In one study only a proportion of gonadotrophs stained with anti-protein kinase-C (PKC) antiserum (Garcia-Navarro et al. 1991) and in others the $\mathrm{Ca}^{2+}$ response to $\mathrm{GnRH}$ was not equal in all gonadotrophs (Leong \& Thorner 1991), and varied in 
cells during the cycle (Tomic et al. 1994). A recent study has revealed that increased intracellular cAMP levels enhance release of LH in some gonadotrophs, and inhibit in others (Cassina et al. 1995). These observations indicate the existence of subpopulations separable on the basis of intracellular processes which are operating.

In this study a static culture system was used. Although pulsatility is not achieved with this technique it allows accumulation of secreted product on the membrane. The concentrations of both GnRH $(0 \cdot 1-1 \mathrm{nM})$ (Sherwood et al. 1980, Ching 1982) and oxytocin (1-10 nM) (Sarkar \& Gibbs 1984, Tannahill et al. 1988) have been measured in portal blood, but the actual levels at a target cell in vivo are uncertain since there is local production of both peptides (Morel et al. 1988, Pagesy et al. 1992) and possibly concentrating mechanisms.

Our study noted, with $2 \mathrm{~h}$ exposure to GnRH, only a small change in numbers of nonsecreting cells, but a large increase in secreting cells and an increase in the total number of immunopositive cells, relative to control incubations. The increase in immunopositive LH, which is necessary to produce the additional numbers of stained cells, is consistent with observations in which increases in immunoreactive LH have been observed after incubating pituitary cells with GnRH (Khar et al. 1978, Ramey et al. 1987, Stojilkovic et al. 1988). Whether this involves transcriptional processes is unclear (Liu \& Jackson 1978, Haisenleder et al. 1991). Alternatively, the increase in immunopositive cells may reflect post-translational processing including translocation of secretory granules to the outer marginal region of the cytoplasm (Lewis et al. 1986). The observation of changes in cell characteristics indicates that $\mathrm{GnRH}$ can modulate the relative proportion of secreting and nonsecreting cells of pro-oestrus pituitaries. The method may have not detected some cells with localised secretion at a surface distant from the blotting membrane. Following $4 \mathrm{~h}$ incubation of pituitary cells with $\mathrm{GnRH}$ there was also an increase in the nonsecreting cell subpopulation.

Therefore, GnRH induces both the appearance of immunopositive material and secretion of immunopositive LH from gonadotrophs. This implies either that cells which were not previously immunocytochemically identified as gonadotrophs convert from another cell type, such as somatotrophs, or were gonadotrophs with low levels of LH which were not detected, or were FSH (single gonadotrophin)-containing cells (Childs 1995). It certainly appears that in pituitary cells demarcations between functional types are not as clear as the traditional model suggested. Indeed, the term somatogonadotroph has been used to describe cells which develop in such a manner (Childs 1995). However, such phenotypic interconversion is possibly more likely to occur within the context of a 4-day oestrus cycle than during a short term in vitro incubation. The possibility, that GnRH stimulates the conversion of monohormonal cells to bihormonal, is strongly suggested by previous observations (Childs 1985, Childs et al. 1994). Thus, considerations of the production of the LH surge will, in a complete version, incorporate the relationship of $\mathrm{LH}$ with follicle-stimulating hormone (FSH) and other factors. The relationship between immunopositive nonsecreting and secreting cells is a fascinating issue.

Additionally, and importantly, it was observed that oxytocin increased the numbers of immunopositive cells. The role of oxytocin in regulation of the ovulatory cycle is still uncertain although it is well established that oxytocin increases release of $\mathrm{LH}$ from dispersed anterior pituitary cells and can interact with GnRH in vivo (Evans \& Tulloch 1995) and on tissue pieces in vitro (Evans et al. 1995). The present increase in immunopositive cells induced by oxytocin reflected an increase more in nonsecreting than secreting cells. It should be borne in mind that oxytocin had a relatively greater positive effect than did GnRH on the subpopulation of immunopositive but nonsecreting cells. This observation is consistent with previous reports that oxytocin is a less potent LH-secretagogue than GnRH. Nevertheless, oxytocin is known to have effects on gonadotrophs, as has been observed with increased inositol phosphate production in $\alpha \mathrm{T} 3-1$ cells (Evans et al. 1997) and increased $\mathrm{Ca}^{2+}$ levels in both $\alpha \mathrm{T} 3-1$ cells and in mature gonadotrophs (Billiard 1996, Evans et al. 1997). Thus, the responsiveness of gonadotrophs to oxytocin is well established. However, the details of the effects of oxytocin on gonadotrophs as they might relate to the physiological condition are uncertain. The results here are consistent with a previous suggestion that oxytocin might be involved at an earlier stage of the production of the $\mathrm{LH}$ surge than $\mathrm{GnRH}$, preparing the pituitary for the arrival of the potent LH secretagogue (Evans et al. 1995). The results suggest that one of oxytocin's physiological roles in the ovulatory cycle may be to increase stores of releasable LH in cells. The $\mathrm{LH}$ would be available to subsequent secretory stimulation by $\mathrm{GnRH}$.

In this study GnRH and oxytocin together did not increase the numbers of immunopositive cells in an additive manner. These results imply that the two agonists act at least partly on the same cells, a result consistent with observations obtained by examining intracellular process in the aT3-1 cell line (Evans et al. 1997). However, the profile of cell response to the mix of peptides was different to that produced by either GnRH or oxytocin alone. This investigation revealed that there are potential complementary processes induced by agonists at the pituitary enabling sequential or concurrent pathways involving hypothalamic peptides to be incorporated into the regulatory mechanisms. These activities must be co-ordinated within the various processes that affect gonadotrophs, including priming, synthesis and desensitisation.

In summary, it was confirmed that GnRH will stimulate pituitary cells to secrete $\mathrm{LH}$, with some individual cells being sensitive to lower levels of GnRH than others. This 
suggests that in vivo there are some gonadotrophs which will respond to the lower levels of $\mathrm{GnRH}$ at the early stages of the preovulatory surge and others which will not release $\mathrm{LH}$ until the GnRH surge is more fully developed. The results confirm therefore, that gonadotrophs are not a homogeneous population of cells. In addition, gonadotrophs responded to exposure to oxytocin. Because oxytocin also did not affect all gonadotrophs identically, there is potential for a complex, and therefore flexible, regulation of the pituitary during the ovulatory cycle.

\section{Acknowledgements}

This investigation was performed with the assistance of the NZ Lottery Grants Board. We are very grateful for the generous gift of immunochemical reagents from NIDDK's National Hormone Pituitary Program and Dr A F Parlow.

\section{References}

Arita J 1993 Analysis of the secretion from single anterior pituitary cells by cell immunoblot assay. Endocrine Journal 40 1-15.

Arita J, Kojima Y \& Kimura F 1991 Identification by the sequential cell immunoblot assay of a subpopulation of rat dopamineunresponsive lactotrophs. Endocrinology 128 1887-1894.

Arita J, Kojima Y \& Kimura F 1993 Measurement of the secretion of a small peptide at the single cell level by the cell immunoblot assay: thyroidectomy increases the number of substance P-secreting anterior pituitary cells. Endocrinology 132 2682-2688.

Billiard J 1996 Functional heterogeneity of pituitary gonadotropes in response to a variety of neuromodulators. Molecular and Cellular Endocrinology 123 163-170.

Cassina P, Sellers J \& Neill JD 1995 Effect of cAMP and GnRH stimulated LH secretion from individual pituitary gonadotropes. Molecular and Cellular Endocrinology 114 127-135.

Childs GV 1985 Shifts in gonadotropin storage in cultured gonadotropes following GnRH stimulation, in vitro. Peptides 6 103-107.

Childs GV 1995 Division of labor among gonadotropes. Vitamins and Hormones 50 215-286.

Childs GV, Ellison DG \& Garner LL 1980 An immunocytochemist's view of gonadotropin storage in the adult male rat: cytochemical and morphological heterogeneity in serially sectioned gonadotropes. American Journal of Anatomy 158 397-409.

Childs GV, Unabia G, Tibolt R \& Lloyd JM 1987 Cytological factors that support nonparallel secretion of luteinizing hormone and follicle stimulating hormone during the estrous cycle. Endocrinology 121 1801-1813.

Childs GV, Unabia G, Lee BL \& Rougeau D 1992a Heightened secretion by small and medium-sized luteinizing hormone (LH) gonadotropes late in the cycle suggests contributions to the LH surge or possible paracrine interactions. Endocrinology 130 345-352.

Childs GV, Unabia G \& Lloyd J $1992 b$ Recruitment and maturation of small subsets of luteinizing hormone gonadotropes during the estrous cycle. Endocrinology 130 335-344.

Childs GV, Unabia G \& Rougeau D 1994 Cells that express luteinizing hormone ( $\mathrm{LH})$ and follicle-stimulating hormone (FSH) $\beta$-subunit messenger ribonucleic acids during the estrous cycle: the major contributors contain LH- $\beta$, FSH- $\beta$ and/or growth hormone. Endocrinology 134 990-997.

Childs GV, Miller BT \& Miller WL 1997 Differential effects of inhibin on gonadotropin stores and gonadotropin-releasing hormone binding to pituitary cells from cycling female rats. Endocrinology 138 1577-1584.
Ching M 1982 Correlative surges of LHRH, LH and FSH in pituitary stalk plasma and systemic plasma of rat during proestrus. Neuroendocrinology 34 279-285.

Dada MO, Campbell GT \& Blake CA 1983 A quantitative immunocytochemical study of the luteinizing hormone and follicle-stimulating hormone cells in the adenohypophysis of adult male rats and adult female rats throughout the estrous cycle. Endocrinology 113 970-984.

Denef C, Hautekeete E, De Wolf A \& Vanderschueren B 1978 Pituitary basophils from immature male and female rats: distribution of gonadotrophs and thyrotrophs as studied by unit gravity sedimentation. Endocrinology 103 724-734.

Evans JJ 1996 Oxytocin and the control of luteinizing hormone. Journal of Endocrinology 151 169-174.

Evans JJ \& Tulloch S 1995 Effects of administration of oxytocin in association with gonadotrophin-releasing hormone on luteinizing hormone levels in rats in vivo. Peptides 16 145-150.

Evans JJ, Hurd SJ \& Mason DR 1995 Oxytocin modulates the luteinizing hormone response of the rat anterior pituitary to gonadotrophin-releasing hormone. Journal of Endocrinology 145 113-119.

Evans JJ, Forrest-Owen W \& McArdle CA 1997 Oxytocin receptormediated activation of phosphoinositidase-C and elevation of cytosolic calcium in the gonadotrope-derived alpha T3-1 cell line. Endocrinology 138 2049-2055.

Garcia-Navarro S, Kalina M \& Naor Z 1991 Immunocytochemical localization of protein kinase-C subtypes in anterior pituitary cells: colocalization in hormone-containing cells reveals heterogeneity. Endocrinology 129 2780-2786.

Haisenleder DJ, Dalkin AC, Ortolano GA, Marshall JC \& Shupnik MA 1991 A pulsatile gonadotropin-releasing hormone stimulus is required to increase transcription of the gonadotropin subunit genes: evidence for differential regulation of transcription by pulse frequency in vivo. Endocrinology 128 509-517.

Johnston CA \& Negro-Vilar A 1988 Role of oxytocin on prolactin secretion during proestrus and in different physiological or pharmacological paradigms. Endocrinology 122 341-350.

Kendall ME \& Hymer WC 1987 Cell blotting: a new approach to quantify hormone secretion from individual rat pituitary cells. Endocrinology 121 2260-2262.

Khar A, Debeljuk L \& Jutisz M 1978 Biosynthesis of gonadotropins by rat pituitary cells in culture and in pituitary homogenates: effect of gonadotropin-releasing hormone. Molecular and Cellular Endocrinology 12 53-65.

Leong DA \& Thorner MO 1991 A potential code of luteinizing hormone-releasing hormone-induced calcium ion responses in the regulation of luteinizing hormone secretion among individual gonadotropes. Journal of Biological Chemistry 266 9016-9022.

Lewis CE, Morris JF, Fink G \& Johnson M 1986 Changes in the granule population of gonadotrophs of hypogonadal (hpg) and normal female mice associated with the priming effect of $\mathrm{LH}$ releasing hormone in vitro. Journal of Endocrinology 109 35-44.

Lewis CE, Richards PSM \& Morris JF 1989 Heterogeneity of responses to LH-releasing hormone and phorbol ester among rat gonadotrophs: a study using a reverse haemolytic plaque assay. Journal of Molecular Endocrinology 2 55-63.

Liu T-S \& Jackson GL 1978 Modifications of luteinizing hormone biosynthesis and release by gonadotropin-releasing hormone, cycloheximide, and actinomycin D. Endocrinology 103 1253-1263.

Lloyd JM \& Childs GV 1988 Differential storage and release of luteinizing hormone and follicle-releasing hormone for individual gonadotropes separated by centrifugal elutriation. Endocrinology 122 1282-1290.

Malagon MM, Garrido-Gracia JC, Torronteras R, Dobado-Berrios PM, Ruiz-Navarro A \& Gracia-Navarro F 1998 Cell heterogeneity as a reflection of the secretory cell cycle. Annals of the New York Academy of Sciences 839 244-248. 
Morel G, Chabot J-G \& Dubois PM 1988 Ultrastructural evidence for oxytocin in the rat anterior pituitary gland. Acta Endocrinologica 117 307-314.

Noguchi K, Arita J, Nagamoto M \& Kimura F 1996 A quantitative analysis of testosterone action on FSH secretion from individual pituitary cells using the cell immunoblot assay. Journal of Endocrinology 148 427-433.

Pagesy P, Li JY, Berthet M \& Peillon F 1992 Evidence of gonadotropin-releasing hormone mRNA in the anterior pituitary. Molecular Endocrinology 6 523-550.

Perez FM, Schwartz J \& Rose JC 1997 Developmental changes in ovine corticotrophs in vitro. Endocrinology 138 916-921.

Ramey JW, Highsmith RF, Wilfinger WW \& Baldwin DM 1987 The effects of gonadotropin-releasing hormone and estradiol on luteinizing hormone biosynthesis in cultured rat anterior pituitary cells. Endocrinology 120 1503-1513.

Robinson G \& Evans JJ 1990 Oxytocin has a role in gonadotrophin regulation in rats. Journal of Endocrinology 125 425-432.

Robinson G, Evans JJ \& Catt KJ 1992 Oxytocin stimulates LH production by the anterior pituitary gland of the rat. Journal of Endocrinology 132 277-283.

Sarkar DK \& Gibbs DM 1984 Cyclic variation of oxytocin in the blood of pituitary portal vessels of rats. Neuroendocrinology 39 481-483.

Sherwood NM, Chiappa SA, Sarkar DK \& Fink G 1980 Gonadotropinreleasing hormone $(\mathrm{GnRH})$ in pituitary stalk blood from proestrous rats: effects of anesthetics and relationship between stored and released GnRH and luteinizing hormone. Endocrinology 107 14101417.

Smith PF \& Neill JD 1987 Simultaneous measurement of hormone release and secretagogue binding by individual pituitary cells.
Proceedings of the National Academy of Sciences of the USA $\mathbf{8 4}$ 5501-5505.

Smith PF, Frawley LS \& Neill JD 1984 Detection of LH release from individual pituitary cells by the reverse hemolytic plaque assay: estrogen increases the fraction of gonadotropes responding to GnRH. Endocrinology 115 2484-2486.

Stojilkovic SS, Chang JP, Ngo D \& Catt KJ 1988 Evidence for a role of protein kinase $\mathrm{C}$ in luteinizing hormone synthesis and secretion. Journal of Biological Chemistry 263 17307-17311.

Tannahill LA, Dow RC, Fairhall KM, Robinson ICAF \& Fink G 1988 Comparison of adrenocorticotropin control in Brattleboro, Long-Evans and Wistar rats. Neuroendocrinology 48 650-657.

Tomic M, Cesnjaj M, Catt KJ \& Stojilkovic SS 1994 Developmental and physiological aspects of $\mathrm{Ca}^{2+}$ signaling in agonist-stimulated pituitary gonadotrophs. Endocrinology 135 1762-1771.

Torronteras R, Castano JP, Almaden Y, Ruiz-Navarro A \& GraciaNavarro F 1993a Hormonal storage patterns and morphological heterogeneity of porcine gonadotrope cells during postnatal development. Molecular and Cellular Endocrinology 97 51-59.

Torronteras R, Castano JP, Ruiz-Navarro A \& Gracia-Navarro F $1993 b$ Application of a percoll density gradient to separate and enriched porcine pituitary cell types. Journal of Neuroendocrinology $\mathbf{5}$ 257-266.

Wei N, Kakar SS \& Neill JD 1995 Measurement of secretogranin II from individual adenohypophysial gonadotropes. American Journal of Physiology 268 E145-E152.

Received 2 February 1999

Accepted 29 June 1999 